\title{
NĚKTERÁ SPECIFIKA BRNĚNSKÉHO HUDEBNÍHO ŽIVOTA VE 2. POLOVINĚ 20. STOLETÍ ANEB EXISTOVALA BRNĚNSKÁ KOMPOZIČNÍ ŠKOLA?
}

Ota Zítek, režisér většiny původních Janáčkových operních premiér, pronesl při otevření Mahenova divadla v roce 1945 krátkou vzpomínku na Leoše Janáčka, kterou zakončil těmito slovy: „A vidím dnes starého pána, jak kráčí brněnskými ulicemi svou kývavou chůzi (jako kachna) s těžkým , platfusem', mohutnou hlavou a hustými bílými vlasy a ř́ká mi: ,Na Brno zvyknete, to je jako mělnické Karlovi IV. zprvu trpké a pak na něj nikdy nezapomenete. Já už bych nikde nemohl žit mimo Brno'.1

V tomto výroku je koncentrováno Janáčkovo vědomí důležitosti brněnského prostředí pro utváření jeho života a tvorby. My však dnes víme, že by bylo možno tvrzení i obrátit v tom smyslu, že právě Janáček byl onou osobností, která utvářela brněnské kulturní prostředí. Podobně jako dvacetiletí před ním Bedřich Smetana v Praze, i Leoš Janáček od osmdesátých let v Brně cílevědomě usiloval o to, aby vytvořil $\mathrm{z}$ tohoto města významné centrum hudební kultury. Činil tak současně v mnoha oblastech: jako sbormistr, dirigent a pianista, jako kritik a publicista, organizátor, pedagog a skladatel. V ohledu oněch posledně jmenovaných činností kolem sebe soustředil skupinu žáků, více nebo méně vděčných za Janáčkův pedagogický vklad do jejich života. K těm méně vděčným patřil Vilém Petrželka, který v roce 1919 publikoval stat' Hudební život brněnský2, v níž kritizoval současný, podle něj špatný stav hudebního života v Brně, za nějž činil zodpovědným právě Janáčka, patřil k nim po předchozím obdivu k Janáčkovi i Jan Kunc, který zamezil tomu, aby se v roce Janáčkových sedmdesátin po něm přejmenovala brněnská konzervatoř - a sama za sebe mohu přidat i hobojistu a skladatele Františka Suchého, který cestou z konzervatoře na tramvaj na Lidickou rád hovoříval o primitivismu Janáčkovy hudební tvorby. O primitivismu psal ostatně také - a to opakovaně - již citovaný Ota Zítek ${ }^{3}$ nebo Vítězslav Novák ${ }^{4}$.

\footnotetext{
1 Sbírky Hudebního oddělení MZM, G 319

2 PETRŽELKA, Vilém. Hudební život brněnský. Hudební revue, 1919, s. 281.

3 ZÍTEK, Ota. Janáček dramatik. Listy Hudební matice, 1924, 4, č. 1, s. 8-11. 
Není třeba se u této skutečnosti zdržovat, je všeobecně známá. Už v roce 1968 ji formuloval Jiř́i Fukač ve své studii Janáčkovská kontinuita ${ }^{5}$ ve které dospěl k závěru, že Janáčkovi prŕmí žáci svému pedagogovi nerozuměli, nebot' príliš předběhl svoji dobu. Fukačova úvaha - která mimochodem vzbudila obsáhlou a ostrou polemiku, jejímiž účastníky byli Osvald Chlubna a Josef Blatný - reflektovala zřejmou skutečnost, že jakkoliv se Janáčkovi žáci ke svému pedagogovi hlásili (to se týkalo právě oněch dvou jmenovaných), své vlastní kompoziční usilování podřizovali dobově preferovanému způsobu dlouhého rozvíjení hudební myšlenky a Janáčkův způsob „kratce, jen kratce“ nechápali, či spíše jim neimponoval, a tudíž nebyli schopni na něj navázat.

Janáčkova snaha vytvořit $\mathrm{z}$ Brna svébytné kulturní centrum tedy potřebovala ke své realizaci čas. Jeho žáci brněnského génia loci ještě nepocit’ovali. To dokládá $i$ fakt, že pokud byli svým rodným místem či krajem nějak inspirováni, bylo to vesměs v rovině obecně folklorních inspirací typu Slováckých, Moravských, prŕpadně Líšeňských lidových tanců, jež psali téměř všichni a jež byly více nebo méně harmonickými a instrumentačními úpravami existujících předloh. Výjimkou byl Osvald Chlubna se svým cyklem symfonických básní To je má zem, jejíž prvá část nese název Brněnské kašny a fontány, ale i tato výjimka je jen zdánlivá: dílo působí koncepcí a jistým archaickým patosem spíše jako jakési myšlenkové prodloužení Smetanovy Mé vlasti.

V padesátých letech se však situace změnila: $v$ komunisty řízeném státě se stal jednou z priorit folklor a Brno jako spádová oblast ještě živého a bohatého folkloru se stalo jedním z jeho nejvýznamnějších center. Své šance se chopilo s velkou chutí. Především vznikl BROLN (Brněnský rozhlasový orchestr lidových nástrojů). Jeho členy byli profesionální hudebníci, jimž měli dodat charakteristickou přirozenou jiskru lidových hudebníků jednak zpěváci z terénu a jednak autoři úprav lidových písní. Z nich jmenujme alespoň dva: Josef Berg napsal pro BROLN nejen velkou řadu úprav, ale i vlastních kompozic, přičemž se asi nezmýlíme, když prohlásíme, že jeho snahy o využití mikrotónového hudebního terénu z přelomu 60. a 70. let ${ }^{6}$ měly svůj původ právě ve folkloru, jak tomu bylo třeba u Aloise Háby. Druhým významným skladatelem ve zmiňovaném ohledu byl Miloslav Ištvan. Na rozdíl od svého př́tele Josefa Berga se věnoval kompozicím pro BROLN poměrně zřídka, zato však soustavně po dobu více než dvaceti let. Folklor byl v Ištvanově kompozičním profilu jedním z určujících činitelů, nebot' od původního zájmu o folklor domácí se později Ištvan obrátil k lidové hudbě jiných zemí a kontinentů. - Tolik ke specifiku Brna, důležitému zejména v 50. letech.

Po 2. světové válce sice Brno ztratilo postavení hlavního zemského města, ale vynahradilo si tuto ztrátu $\mathrm{v}$ jiných ohledech. Především byla výhodou jeho

vovatelem mé hyperpolyfonie“ - výrok Vítězslava Nováka o Břetislavu Bakalovi. NOVÁK, Vítězslav. Paméti, s. 344. 
geografická pozice. Bylo (a je) dosti daleko od Prahy a vzhledem k tomu nebylo tak ostře ideologicky sledováno jako Praha ${ }^{7}$. Mohly se v něm tudíž prosadit i myšlenky v Praze nepř́pustné, třeba dodekafonie. A dále byla podstatná blízkost Vídně, která i v době hraniční neprostupnosti byla dosažitelná díky rozhlasovému a později i televiznímu vysílání (což Praha neměla) a umožňovala tak aktuální informovanost jak politickou, tak kulturní (vzpomínám ještě dnes na pravidelné tuším úterní - večerní relace Neue Musik Lothara Knessla se znělkou z Varèsovy skladby Hyperprism, které nám otevíraly horizonty dokořán). Nepřekvapí tedy, že právě v Brně byla napsána kniha, která $\mathrm{v}$ šedesátých letech sloužila jako vyhledávaná informace o současných kompozičních technikách - Novodobé skladebné teorie západoevropské hudby Ctirada Kohoutka (1962). Byla natolik žádaná, že hned v roce 1965 vyšlo její druhé, podstatně přepracované a rozššřené vydání s názvem Novodobé skladebné směry v hudbě. Dále: v Brně v roce 1961 vznikl a působil první český soubor orientovaný na avantgardní produkci-Musica nova (Josef Horák, Oldřiška Vaňharová a Branko Čuberka) a v Brně byla také v roce 1960 napsána první česká dodekafonická skladba, Suita à 12 Pavla Blatného.

Dalším specifikem Brna na počátku 2. poloviny 20. století byla situace v divadelní oblasti. Uměleckým šéfem činoherní scény se stal roku 1959 př́slušník nastupující generace Miloš Hynšt, který kolem sebe soustředil své vrstevníky a spolupracovníky, vesměs mimořádné umělecké osobnosti: $\mathrm{z}$ režisérů to vedle Hynšta byli Evžen Sokolovský a Alois Hajda, dramaturg Bořivoj Srba, z výtvarníků Miloš Tomek, Ladislav Vychodil a Konrád Babraj, ze skladatelů Josef Berg, Pavel Blatný, Miloslav Ištvan, Jan Novák a Zdeněk Pololáník. Mezi přední herce patřili Vlasta Fialová, Jaroslav Dufek, Josef Karlík, Helena Kružíková, Ladislav Lakomý a další. Už jen tento soubor jmen naznačuje, že v Brně mělo divadlo velmi silnou pozici. Ostatně se tehdy stavěla nová operní budova, která byla otevřena 1965 a patřila k prioritám kulturní politiky doby. V souvislosti se stavbou se ostatní divadelní scény přemist'ovaly, vesměs do lepších a reprezentativnějších prostor. A v neposlední řadě je třeba dodat, že vedle scén Státního divadla existovala ještě sít' městských divadel, z nichž zejména Večerní Brno inscenacemi her Milana Kundery, Václava Havla, Milana Uhdeho a dalších mělo výsadní postavení.

Příprava inscenací byla společnou prací všech zúčastněných a činohra Státního divadla v Brně se tak stala tribunou názorového tř́bení a sjednocující platformou umělců různých profesí, leč obdobných názorů. Pro ilustraci volím opět př́klad z tvorby Miloslava Ištvana, který od šedesátých let považoval spolupráci s divadlem za „laboratoř, v niž si ověruje své nápady $i$ větši koncepce“. ${ }^{8}$ Prvním významným výsledkem tohoto „laboratorního“ prístupu byla scénická hudba ke hře Georga Büchnera Vojcek. Byla to inscenace důležitá jak pro režiséra Hajdu, kte-

7

Ještě lépe na tom byl Zlín - Gottwaldov, kam v době normalizace odcházely nejvýznamnější osobnosti z podobných důvodů - že tam nacházely relativní klid k práci: Evžen Sokolovský, Alois Hajda, Miroslav Plešák ad.

8 Ištvanovy rukopisné poznámky pro rozhlasovou besedu, viz: BÁRTOVÁ, Jindřiška. Miloslav Ištvan. Brno, JAMU 1997, s. 48. 
rý s ní poprvé vstoupil na scénu Mahenova divadla (premiéra se konala 16. 11. 1962), tak pro Ištvana, který si v ní poprvé ozkoušel - vedle nosnosti materiálu a zvukového působení zvoleného nástrojového obsazení - také princip rodícího se způsobu své kompoziční práce - montáže. Mimořádně zajímavé je v této souvislosti zjištění, že Hajdova brněnská inscenace Vojcka byla režijně postavena na ostře vyhrocených simultánních výjevech ${ }^{9}$. Princip Ištvanovy montáže byl v určitém smyslu analogií tohoto režijního pojetí.

Umělci byli v době totality organizováni v uměleckých svazech. Ty byly v 50 . letech především ideologickými institucemi, jejichž úkolem bylo hlídat „správné" umělecké postupy. Na jaře roku 1963 však došlo právě v Brně na půdě Svazu československých skladatelů k něčemu zcela mimořádnému, bezprecedentnímu, když vznikla skladatelská Skupina $A{ }^{10}$ Jejími členy byli Josef Berg, Miloslav Ištvan, Jan Novák, Alois Piňos a Zdeněk Pololáník. Skupina realizovala své představy na samostatných koncertech s atraktivními způsoby prezentace (happeningy, grafická hudba, audiovizuální projekty, týmové kompozice) a později dokonce s vlastním orchestrem Studia autorů. Skupina fungovala po celá šedesátá léta a zanikla až se zánikem Svazu československých skladatelů.

Skupina A představovala výrazné specifikum hudebního Brna. K dalším specifickým skutečnostem je třeba připočítat ještě v letech 1969 a 1970 pořádanou Expozici experimentální hudby, která s činností Skupiny A více nebo méně souvisela, představujíc podobný dramaturgický i prezentační koncept; zejména je ovšem třeba zmínit veřejné nahrávky nových orchestrálních skladeb, uskutečňované dvakrát do roka brněnskou filharmonií ve spolupráci se Svazem československých skladatelů. Byly pořádány $\mathrm{v}$ rozhlasovém studiu Dukla na Kounicově (tehdy Leninově) ulici za prŕitomnosti publika jako „live“ nahrávka, což byla v době studiového nahrávání skladeb po částech, za pomoci střihů, pozoruhodná novinka. Na těchto studiových koncertech zazněly obvykle tři i čtyři orchestrální premiéry, nejčastěji brněnských skladatelů, prostor však dostávali i interpreti pro vystoupení s orchestrem. Vzhledem $\mathrm{k}$ tomu, že všechny tyto akce byly nahrávány a posléze vysílány a že existovaly přibližně od poloviny 60 . let ${ }^{11}$ až do roku 1989 , šlo o zcela mimořádný př́nos současné tvorbě (jen hrubým odhadem lze říci, že bylo takto uvedeno $\mathrm{v}$ život až na sto současných orchestrálních skladeb!). V žádném dalším českém městě taková akce neprobíhala, lze tedy hovořit o vskutku mimořádném brněnském specifiku.

9 Recenze Viktora Kudělky v Divadelních novinách z 29. 12. 1962 uvádí svlékání Vojcka $\mathrm{u}$ doktorů a vedle toho Mariinu nevěru, nebo scénu, v níž Vojcek kupuje vražedný nůž, zatímco Marie čte kajícně bibli.

10 Skupina A vyhlásila svoji existenci na jaře 1963 a její první koncert se uskutečnil 8. 3. 1964.

11 Přesný počátek a iniciátora jejich vzniku je dnes už obtížné zjistit, nejpravděpodobnější je rok 1963 a mezi iniciátory byl určitě Josef Berg, který už dříve pořádal pro Skupinu A na půdě Čs. rozhlasu koncerty Studia autorů. V čele spolupořádajících institucí tehdy působili dirigent Jiří Waldhans, dramaturg Vladimír Telec a ředitel František Ostrý (Stání filharmonie Brno), tajemník brněnské pobočky SČS Jiří Matys a redaktor Čs. rozhlasu Zdeněk Zouhar. 
A abychom byli úplní, nelze pominout ani existenci Mezinárodních hudebnich festivalů Brno, které od svého prvého ročníku 1966 věnovaly pozornost současné produkci v reprezentativních, většinou podvečerních koncertech, navštěvovaných vedle domácího publika také četnými zahraničními účastníky festivalu, což se pozitivně odráželo v povědomí o českých skladatelích a interpretech v cizině.

Potud tedy specifika hudebního Brna ve 2. polovině dvacátého století. Už při jejich výčtu se objevila některá skladatelská jména, jež s nimi nedílně souvisela. Především to byla jména členů Skupiny A. Skupina však, jak jsme už řekli, zanikla v souvislosti s politickou situací na počátku 70. let a hudební život Brna se výrazně změnil: Jan Novák, do té doby nejreprezentativnější představitel brněnské skladatelské obce (už proto, že byl žákem Martinů), emigroval, a Josef Berg, nejagilnějšś z organizátorů všemožných akcí, na počátku roku 1971 zemřel. Pozornost se tedy stále více soustřed’ovala k Miloslavu Ištvanovi, skladateli s nezpochybnitelným tvưrčím i lidským kreditem (pro ilustraci: poté, co přijely v srpnu 1968 sovětské tanky, byl na spontánně uspořádaném shromáždění členů SČS zvolen vedoucím brněnské pobočky právě Ištvan a ten tuto funkci při plném vědomí její riskantnosti přijal).

Miloslav Ištvan dospěl ve druhé polovině 60. let ke svému osobnímu způsobu kompozice, který formuloval i teoreticky ve spise Metoda montáže izolovaných prvků v hudbě (1965), v němž uvedl mj., že se jeho pokus opírá o ,podněty z díla Leoše Janáčka a hned za ním z dila A. Weberna; Janáčkovo pojetí hudebni myšlenky jako krátkého, $v$ sobě uzavřeného a jednoznačného celku; pojetí polyfonie a formy jako kontrapozice takto utvárených prvkü; webernovské rozbití vnějši kontinuity, atomizace formy, pohybu, linie na (zdánlivě) izolované mikroprvky “. ${ }^{12}$

Zdůrazněme, že jako první východisko uvádí Ištvan Janáčka, jehož význam pro svoji tvorbu ostatně zmiňoval i jindy: „Nejbliže mi byl vždy Janáček. [...] Myslím, že Janáček objevil to nejpodstatnějši - nové možnosti pro vytváreni originálních souvislostí ve všech hudebnich parametrech za použití ne přiliš komplikovaných struktur (nekomplikovaných třeba ve srovnání s technikou Arnolda Schönberga). Janáčkova hudba je mi jako posluchači vủbec nejbližší. Jsem schopen ji poslouchat neanalyticky, což se skladateli nepodaři často. Autorský vztah je dvojaký; celý život se budu varovat položit vedle sebe dvě noty, které by Janáčka připomínaly - to je velmi nebezpečné. Zato ale těžko najdu někdy jiné základni principy, které by mi vyhovovaly lépe než janáčkovské. “13

Ištvanovým zdůrazňováním janáčkovského východiska se dostáváme velkým obloukem k počátku našeho referátu. Právě Ištvan se stal prvním ze skladatelů, kteří dokázali tvưrčím zpưsobem na Janáčka navázat.

12 IŠTVAN, Miloslav. Metoda montáže izolovaných prvkư v hudbě. Brno, 1973, s. 12.

13 DRLÍKOVÁ, Eva. O rehumanizaci soudobého hudebního jazyka (rozhovor s M. Ištvanem). Opus musicum, 1979, 11, s. 116. 
Miloslav Ištvan byl typem stále hledajícího umělce, který potřebuje o svých úvahách s někým diskutovat. Také proto se stal velmi oblíbeným pedagogem, $\mathrm{k}$ němuž se na JAMU sjižděli nadějní komponisté z celé tehdejší ČSSR. Byly jich dvě desítky a všichni bez výjimky se po Ištvanově smrti v roce 1990 vyjádřili v tom smyslu, že Ištvan vytvořil jakousi ,školu“, nebot' jím definovaný kompoziční způsob montáže izolovaných prvků v hudbě byl natolik flexibilní, že jej mohli používat i jiní bez rizika epigonství.

Ištvanovo působení na další brněnské umělce, jeho mladší kolegy a přátele, se projevilo nejzávažnějším způsobem v první etapě působnosti skupiny Camerata Brno. Byla to zprvu neformální setkávání brněnských skladatelů a teoretiků, jež Ištvan inicioval $\mathrm{v}$ době, kdy nebylo možno na oficiálních platformách dost dobře hovořit o umění (první schůzky se uskutečnily koncem 70. let) a - jak výstižně napsal Karel Šimandl - Ištvan byl tou osobností, která byla $v$ tomto prostředí určující a s jejímiž názory se při setkáních nepolemizovalo. ${ }^{14}$

Skutečnost, že existovala brněnská kompozični škola, dokládají i dobové materiály. První náznak objevíme v již citované studii Jiř́ho Fukače z roku 1968, v níž autor použil výroku „mladí kolem Ištvana “. ${ }^{15} \mathrm{~V}$ roce 1983 Jan Vičar ve studii Skladatelská generace sedmdesátých let, názory a orientace výslovně uvádí: „Již od dob Janáčkových müžeme hovořit v českých zemích o dvou skladatelských školách - pražské a brněnské. Polarita těchto škol se značně vyhrotila od konce padesátých let $v$ souvislosti i s pronikáním Nové hudby. Zatímco brněnská škola byla orientována avantgardněji, poučena na výdobytcich polské skladatelské a západni avantgardy, tradičněji orientovaná pražská škola nadále rozvijela dvořákovsko-novákovskou tradici. Rozdíl v zaměrení trvá dodnes. ${ }^{\text {"16 }} \mathrm{A}$ Josef Bek v roce 1985 ve studii 40 let tvorby současných českých skladatelů jde ještě dále, když dává do přímé souvislosti brněnskou skladatelskou školu a Ištvana (,Přitažlivost brněnské školy násobily skladatelské úspěchy Miloslava Ištvana, který se $v$ prüběhu 70. let stal na Moravě vưdči osobnosti"). ${ }^{17}$

Soustavně a v historickém vývoji sleduje problematiku Jaromír Havlík v knize Česká symfonie z roku 1989. Konstatuje nejprve, že „ve druhé polovině šedesátých let se postupně vyhraňovala osobitá tvưrči poetika skupiny mladých brněnských skladatelü,“ z nichž řada „výrazněji akceptovala podněty Nové hudby a na jejich základě vytvárela vlastni kompozični systémy i komplexnějši tvưrči poetiky “18 a v souvislosti s lety sedmdesátými dospívá k závěru, že je „,v připadě Prahy a Brna již vcelku oprávněné hovořit o skladatelských školách “ ${ }^{19}$ Podobnou

14 Dopis Karla Šimandla autorce ze dne 7. 4. 1997.

15 FUKAČ, Jiř́i. Janáčkovská kontinuita? Hudební rozhledy, 21. 1968, s. 113-116.

16 VIČAR, Jan. Skladatelská generace sedmdesátých let. Názory a orientace. Opus musicum, 1983, 17, č. 4, s. 106.

17 BEK, Josef. 40 let tvorby současných českých skladatelů. Opus musicum, 1985, 19, s. 161162.

18 HAVLÍK, Jaromír. Česká symfonie 1945-1980. Praha, 1989, s. 238.

19 Ibid., s. 303. 
formulaci uvádí Havlík i v závěrečných pasážích své knihy, v nichž pojem „skladatelská škola“ dává do souvislosti s ,poněkud odlišným nasměrováním výchovy skladatelského dorostu na pražské a brněnské vysokoškolské katedře“, přičemž skladatelé vyšlí z pražské katedry ,jsou vyškoleni s větším dưrazem na tradici“, zatímco „brněnské prostředí se, nesporně též pod silným vlivem janáčkovského kultu, z této vazby k tradici postupně více uvolnilo a akceptovalo výrazněji moderni tendence umélecké tvorby"20.

Tolik postř̌ehy některých z předních českých muzikologů zabývajících se problematikou soudobé tvorby. Týkaly se vesměs české tvorby sedmdesátých až osmdesátých let. Po listopadu 1989 se změnila společenská i kulturní situace, v lednu 1990 zemřel Miloslav Ištvan a brněnská kompoziční škola se stala minulostí. Bohužel.

Jindřriška Bártová je vedoucí Katedry hudebních a humanitních věd Hudební fakulty JAMU v Brně. Přednáší dějiny hudby, hlavní oblastí jejího zájmu je česká hudba 20. století. Publikovala přes 70 studií a knihy: Jan Kapr (1994), Miloslav Ištvan (1997), Camerata Brno (2003), Režijní př́istupy k operám Leoše Janáčka v Brně (2004, spoluautorka Monika Holá), Přemítání nejen o hudbě (2010).

\begin{abstract}
:
Brno became a center of musical culture in the late $19^{\text {th }}$ century thanks to versatile activities of Leoš Janáček. His disciples, however, not establish its activities, the efforts of their teachers did not understand. The situation changed after the World War II, when composers in Brno tried to experience and use contemporary compositional techniques, especially dodecaphony and the New music. They were mostly members of Group A. This group disappeared in the 1970s and the attention then focused on her former member Miloslav Ištvan. Ištvan followed Janáček and Webern in his compositional method "montage of isolated sound elements in music." Concentrated around like-minded colleagues and pupils at the end of the 1970s, group Camerata Brno was established, which was known in professional circles as "the Brno compositional school".
\end{abstract}

\title{
Key words:
}

Brno, Leoš Janáček, composers, Group A, Miloslav Ištvan, Camerata Brno, Brno compositional school

\section{Bibliography:}

BÁRTOVÁ, Jindřiška. Miloslav Ištvan. Brno, JAMU 1997.

BEK, Josef. 40 let tvorby současných českých skladatelů. Opus musicum, 1985, 19, s. 161-162. 
DRLÍKOVÁ, Eva. O rehumanizaci soudobého hudebního jazyka (rozhovor s M. Ištvanem). Opus musicum, 1979, 11, s. 116.

FUKAČ, Jiří. Janáčkovská kontinuita? Hudební rozhledy, 1968, 21, s. 113-116.

HAVLÍK, Jaromír. Česká symfonie 1945-1980. Praha, 1989, s. 238.

IŠTVAN, Miloslav. Metoda montáže izolovaných prvki̊ v hudbě. Brno, 1973.

NOVÁK, Vítězslav. O sobě a o jiných. Praha, 1970.

PETRŽELKA, Vilém. Hudební život brněnský. Hudební revue, 1919, s. 281.

VIČAR, Jan. Skladatelská generace sedmdesátých let. Názory a orientace. Opus musicum, 1983, 17, č. 4 , s. 106.

ZÍTEK, Ota. Janáček dramatik. Listy Hudební matice, 1924, 4, č. 1, s. 8-11. 